\title{
UNIVERSITYOF
}

FORWARD

THINKING

WESTMINSTER用

WestminsterResearch

http://www.westminster.ac.uk/westminsterresearch

Creating the collective: social media, the Occupy Movement and its constitution as a collective actor

Kavada, A.

This is an Accepted Manuscript of an article published by Taylor \& Francis in Information, Communication \& Society, 18 (8), pp. 872-886, 2015, available online:

http://www.tandfonline.com/https://dx.doi.org/10.1080/1369118X.2015.1043318.

The WestminsterResearch online digital archive at the University of Westminster aims to make the research output of the University available to a wider audience. Copyright and Moral Rights remain with the authors and/or copyright owners.

Whilst further distribution of specific materials from within this archive is forbidden, you may freely distribute the URL of WestminsterResearch: ((http://westminsterresearch.wmin.ac.uk/).

In case of abuse or copyright appearing without permission e-mail repository@westminster.ac.uk 


\section{Creating the Collective: Social Media, the Occupy Movement and its Constitution as a Collective Actor}

Anastasia Kavada

Senior Lecturer

School of Media, Arts \& Design

University of Westminster

Email: A.Kavada@westminster.ac.uk

Telephone: +447789008037

Address: Harrow Campus, Northwick Park, Watford Road, Harrow, MIDDX HA1 3TP, UK

The fieldwork for this research was funded by a British Academy Mid-Career Fellowship, Award number: SCHW08. This research has been co-financed by the European Union (European Social Fund - ESF) and Greek national funds through the Operational Program "Education and Lifelong Learning" of the National Strategic Reference Framework (NSRF) - Research Funding Program: ARCHIMEDES III. Investing in knowledge society through the European Social Fund, which provided the researcher with additional time for writing this article. 


\section{Abstract:}

This paper examines the process through which Occupy activists came to constitute themselves as a collective actor and the role of social media in this process. The theoretical framework combines Melucci's (1996) theory of collective identity with insights from the field of organizational communication and particularly from the 'CCO' strand - short for 'Communication is Constitutive of Organizing'. This allows us to conceptualize collective identity as an open-ended and dynamic process that is constructed in conversations and codified in texts. Based on interviews with Occupy activists in New York, London and other cities, I then discuss the communication processes through which the movement was drawing the boundaries with its environment, creating codes and foundational documents, as well as speaking in a collective voice. The findings show that social media tended to blur the boundaries between the inside the outside of the movement in a way that suited its values of inclusiveness and direct participation. Social media users could also follow remotely the meetings of the general assembly where the foundational documents were ratified, but their voices were not included in the process. The presence of the movement on social media also led to conflicts and negotiations around Occupy's collective voice as constructed on these platforms. Thus, viewing the movement as a phenomenon emerging in communication allows us an insight into the efforts of Occupy activists to create a collective that was both inclusive of the $99 \%$ and a distinctive actor with its own identity.

Keywords: social media, Occupy, social movements, internet, collective identity, representation 


\section{Introduction}

Inspired by a call to occupy Wall Street circulated by the Canadian magazine Adbusters, the Occupy movement began on the $17^{\text {th }}$ of September 2011 when activists occupied Zuccotti Park in Downtown Manhattan. The movement spread quickly as within its first six months 6500 people were arrested and Occupy groups were set up in more than 1000 cities (Costanza-Chock, 2012).

Occupy can be seen as part of a broader wave of 'movements of the squares' (Gerbaudo, 2012) that emerged with the Arab Spring in 2011, with the latest mobilization starting in Hong Kong in September 2014 when activists camped in front of the government headquarters asking for electoral reform. Although the 'movements of the squares' have appeared in different political regimes and have different demands, they all seem to share some characteristics in common: the occupation of public space, the lack of recognizable leaders, an emphasis on inclusiveness, and a belief in democracy and justice (Castells, 2012; Juris, 2012). Occupy activists railed against economic inequality and the capture of the political system by economic interests and attempted to build a community of equals by practicing the methods of participatory democracy (Juris, 2012).

The use of digital media is thought to have played an instrumental role in the quick diffusion of the movement and the mobilization of participants. Facebook pages were used to rally the public, to elicit feedback from members and to build solidarity (Gaby \& Caren, 2012). At the same time, tech and media activists established alternative print media publications, like the Occupied Wall Street Journal, and built autonomous technological infrastructure like the NYCGA.net and InterOccupy.net platforms (Costanza-Chock, 2012). They also operated '24-hour livestreams such as Globalrevolution.tv' (ibid: 4) which at peak times garnered more than 80,000 unique viewers per day (ibid, p. 8). As Gamson and Sifry (2013) put it, '[w]ithout user-generated and noncorporateowned media, it is unlikely that the Occupy movement might have ever gotten traction' (p. 159).

Focusing on social media, this article investigates how Occupy activists in the UK and the USA created a sense of the collective through their practices of communication. The empirical research mainly derives from interviews with activists and the analysis of documents and online material. To 
set the background for this analysis, I first review theory around the relationship between social media and collective action and particularly the claims that social media lead to more decentralized forms of activist organizing and looser types of political engagement. I then explain the theoretical framing of this study which is based on Melucci's conceptualization of collective identity combined with theories of organizational communication.

\section{Social media and collective action}

The role of social media in protest movements is a fiercely contested issue. Scholars note the capacity of social media for the quick aggregation of publics around contentious issues and their potential for flash mobilizations, a type of collective action that requires 'only ephemeral engagements from participants' (Earl et al., 2014, p. 1). This has raised questions around the empowering role of social media since they seem to facilitate mobilizations based on shallow commitments that fail to build long-standing relationships (Gladwell, 2012). As Dean (2012) notes, '[c]ommunication technologies contribute to the displacement and dispersion of critical energy such that even as inequality has intensified, forming and organizing a coherent opposition has remained a persistent problem' (p. 126).

The internet can provide more power to entrepreneurial activists who can organize protests without the resources and structures offered by conventional organizations (Chadwick, 2013; Bimber, Flanagin \& Stohl, 2012). This facilitates 'organizing without organizations' (Earl et al., 2014) as it permits the coordination of collective action without costly and complex organizational infrastructures (della Porta and Mosca, 2005). The internet is also changing the membership structures of current social movements as it allows people to join a cause with just one 'click', thus challenging established views of what it means to be a 'member' (Chadwick, 2013).

Yet, it is the potential of social media platforms to constitute collectives that seems to mainly divide authors. Fenton and Barassi (2011) suggest that proprietary platforms are built with individual networking in mind and are thus unsuitable for the creation of collective solidarity. Proprietary 
platforms are geared towards corporate surveillance since their owners profit from the data and content produced by registered users (Fuchs, 2014). Juris (2012) has also remarked on the individualizing dynamics of such platforms, noting that they facilitate the aggregation of individuals around common causes but not the development of a common identity which is fostered more easily through face-to-face communication.

Conversely, Bennett and Segerberg (2013) emphasize the empowering potential of social media, suggesting that such platforms are generating a distinct form of protest activity that they call 'connective action'. In connective action 'participants engage with issues largely on individual terms by finding common ground in easy-to-personalize action frames that allow for diverse understandings of common problems to be shared broadly through digital media networks' (Bennett, Segerberg \& Walker, 2014, p. 233). The term refers to how self-organized activist networks operate in their 'ideal type' when formal organizations do not take a lead role. Instead, coordination is based on digital technologies which thus become 'important organizational agents' (Bennett \& Segerberg, 2012, p. 755). But how can activists create coherent organization through digital media in such self-organized networks? Bennett, Segerberg and Walker (2014) answer this question empirically through the analysis of tweets devoted to Occupy Seattle. They distinguish 'a set of elemental processes' (ibid: 239) which include the production, curation and dynamic integration of information. These processes explain how stitching technologies such as Twitter can lend organization to the broader crowd' (ibid)..

The identification of these mechanisms and the framework of 'connective action' constitute important advances in the field. Yet, what still remains unclear is whether the logic of 'connective action' applies to the whole of the movement or to specific types of participants who do not form part of its core and are thus more loosely connected to the collective and its identity. In this respect, Bennett and Segerberg tend to refer to the 'crowd' and their empirical analysis treats all Twitter accounts in the same manner, without making distinctions between Occupy collective accounts and individual accounts for instance (for a similar critique see Karpf, 2014). A related question refers to whether 'connective action' characterizes mostly the activities observed on social 
media or also those on other platforms and physical spaces.

Once we start to open up the vista, we may observe that alongside the looser networking afforded by social media, there also processes in place that traverse both online and offline spaces where a group of activists come to consider themselves as a movement. It is these processes that form the core of the analysis in this paper. These include processes through which the collective becomes aware of itself, distinguishes itself from its environment and operates as an actor with agency. In other words, the processes that I am interested in here entail more conventional collective action organizing than the one discussed by Bennett and Segerberg. In contrast to current research on the role of social media which emphasizes how their use may be antithetical to the development of the collective, in this paper I focus on the place of social media in communication processes that render an aggregation of individuals into a collective which although loose and decentralized still constitutes a distinct collective actor. To develop a conceptual framework for this enquiry, I turn to Melucci's theorization of collective identity and combine it with insights from organizational communication.

\section{Conceptual Framework: Collective identity and Organizational Communication}

The concept of collective identity as defined by Melucci offers a useful framework for conceptualizing the process through which collectives are formed and continuously redefine themselves and their boundaries. Melucci (1996) views collective identity as 'an interactive and shared definition produced by a number of individuals (or groups at a more complex level) concerning the orientations of their action and the field of opportunities and constraints in which such action is to take place' (p. 70). It is a process through which participants in collective action can reflect on the membership and boundaries of the group, as well as on its vision, resources and relationship with the environment (Johnston, Larana \& Gusfield, 1994).

In contrast to approaches that treat collective identity as a product, Melucci considers it as a 
dynamic and open-ended process. He urges scholars to use of the term 'identization' rather than 'identity' (Melucci, 1996, p. 77) and to strive to understand how the collective becomes a collective through 'multiple and heterogeneous social processes' (Melucci, 1996, p. 20). Melucci's definition of the concept suggests that collective identity should not be considered as a unitary or even coherent definition of the group's shared attributes, but can be multiple and diverse (Author, 2009a; Flesher Fominaya, 2010). The content of collective identity comprises not only statements about what the group is about, but also its common practices. This is particularly the case for prefigurative movements which are more focused on building alternative communities and for whom their way of doing things is instrumental to their sense of who they are. Furthermore, the process of identization includes both emotional and cognitive components as it involves both common definitions and the development of feelings of solidarity (Author, 2009a; Flesher Fominaya, 2010).

Thus in Melucci's use of the concept, collective identity becomes something more than simply a shared definition of the group. Viewing collective identity as an open-ended process through which a collective becomes a collective, Melucci employs the concept to study how a group constitutes itself as an actor that is distinct from its environment and that has a certain agency. This entails an interactive process based on a network of active relationships which are shaped by the collective's forms of organization and leadership, as well as by its media and communication technologies (Melucci, 1996, p. 71). Melucci is however less clear about how this interactive process takes place and how communication technologies affect the process of 'identization'.

This is where the concept can benefit from the import of communication theory which can help us to conceptualize the interactive processes that underlie collective identity formation. The need to understand these processes is rendered even more pressing with the emergence of the internet which marks a shift in how we perceive the role of media in collective action. The emphasis on digital media as 'organizing tools' has meant that research on the topic focuses not only on how already existing collectives use media to communicate with the public, but also on how the activists' media practices are constituting collectives (see also Author, 2014). 
Thus, it is no surprise that communication is at the centre of new frameworks like Bennett and Segerberg's 'connective action'. Developing a communication approach to collective action is also the express purpose in a set of publications by Bimber, Flanagin and Stohl (2012) who 'reframe collective action as being constituted by a set of communication practices involving the crossing of boundaries from the private to the public realm' (Flanagin, Stohl and Bimber, 2006, p. 32). Earl et al. (2014) also 'argue that the widescale use of ICTs should change how we study SMs [Social Movements] by forcing greater integration between research on political communication (PC) and SM studies' (p. 5, emphasis in original). Other scholars in the field have attempted to incorporate a communication approach to theories of collective action. For instance, Mattoni and Treré (2014) turn to the concepts of mediation and mediatization, while Costanza-Chock (2014) has developed the notion of transmedia mobilization.

In line with the aforementioned scholars, this paper takes a communication approach to collective action, combining Melucci's theory with insights from an emerging strand in organizational communication called 'CCO' - short for 'Communication is Constitutive of Organizing', its foundational principle (Putnam, Maydan Nicotera \& McPhee, 2009). My focus within this strand is particularly on the 'Montreal School' and the work of Taylor and van Every (2000). ' In their seminal book, 'The Emergent Organization', Taylor and van Every (2000) argue that organizations emerge in two communicative conditions, 'conversation' and 'text'. By 'conversation' they mean the shared interactions occurring in everyday situations when people come together to coordinate around specific objectives (p.35). Conversations are shaped by and recorded in texts that fix and codify the organization and allow it to scale and to transcend the time and place of the interaction (p. 34). However, as Taylor and van Every (2000) propose, we can view 'text' and 'conversation' in much more expansive terms, considering 'conversation' as 'an essential sociality' (p. 31) and text as 'a structuring principle' which entails any stable patterning or recording of interactions, ideas, values, roles, and rules. In this respect, 'text' takes the notion of 'code' and can include the architecture of buildings, software code, ideological frameworks, legal rules and informal codes of conduct (Cooren \& Fairhurst, 2009). 'Text' and 'conversation' co-constitute each other and together, they form 'a 
self-organizing loop' (Taylor \& van Every, 2000, pp. 210-211).

Applying CCO theory to Melucci's understanding of collective identity, we can consider the process of 'identization' to take place in a set of conversations that crystallize in 'texts' or 'codes' which in turn encapsulate and codify the movement's identity. In line with Melucci, these 'codes' can refer not only to the goals and ideology of the movement, but also to the codification of rituals and practices. In the case of the Occupy movement, for instance, these 'codes' concern both common statements and formalized behaviours like the code of conduct and hand signals employed in general assemblies. In turn, these 'codes'/'texts' can shape future interactions around collective identity as the movement dynamically alters and revises its sense of self. Furthermore, the boundaries, visibility and accessibility of the movement's conversations are constitutive of the ways in which the collective actor distinguishes between the inside and the outside of the movement, an important aspect of collective identity formation.

But what is the role of media in these processes? Taylor and van Every's (2000) work is less useful here as empirical research applying the CCO framework tends to consider 'conversation' as a faceto-face phenomenon and 'text' as written documents. In this respect, actor-network theory, as well as writings on how software code conditions interaction can offer useful entry points in conceptualizing the role of media in texts and conversations. For instance, drawing from Deleuze and Guattari, Langlois et al. (2009) suggest that 'there is a need to pay attention to how politics mobilize code at the same time as code formalizes politics according to specific informational logics.' (p. 417) For them, 'code' includes the platform, software, networks, informational dynamics and other components of digital media through which communication takes place. In his book, 'Code: and Other Laws of Cyberspace', Lessig (2000) takes a similar perspective, noting how the architecture of media platforms can regulate behaviour.

Yet, my suggestion is to employ the notion of 'code' or 'text' in broader terms so that it encompasses not only software code, but also the norms, regulations, architecture and business models that underlie the design of media platforms. In other words, media platforms can be 
considered as both socio-cultural and techno-commercial phenomena (van Dijck, 2013). The codes of media platforms influence the spatiality and temporality of conversations or, in other words, how they are arranged in time and space, as well as their visibility and accessibility. They also affect

the 'encoding' of the conversations occurring through them as they have different affordances with regards to the recording or 'textualization' of interactions. They thus generate different formats of 'texts' with varying degrees of portability and durability through time.

To avoid a technologically deterministic position, we further need to take into account not only how the design of media platforms enables and constrains certain uses, but also how this design is itself is shaped by a specific social context, as well as by the intentions and practices of the designers. Users also have their own cultures, intentions and practices and may use the platforms in ways that they were not originally designed for (Author, 203; Barassi and Treré, 2012).

Based on the foregoing discussion, I propose that we conceptualize collective action as emerging in interconnected and overlapping texts and conversations that unfold in conversation sites with varying spatialities and temporalities in which people come together to coordinate and act collectively. In what follows, I use this conceptualization to discuss the ways in which the activists' social media practices helped to 'create the collective', to constitute the Occupy movement as an actor with its own collective identity.

\section{Methods}

This paper draws its empirical material from in-depth interviews with 75 Occupy activists from Occupy London, New York, Boston and Seattle. 41 interviewees were active in Occupy Wall Street, the first and most iconic Occupy encampment where some of the movement's foundational practices and slogans originated from. I also interviewed 10 activists from Occupy Boston, 1 from Sacramento and another 13 from Seattle in order to investigate case studies of smaller occupations in the USA situated in both the East and the West Coast. The remaining 10 interviewees were active in Occupy London, one of the main non-US occupations. The interviewees included mainly core activists, particularly those who were members of the press, media, tech and facilitation working 
groups, as well as activists responsible for Livestreaming and the movement's publications. However, the insights of those with a more peripheral role in the occupations were also sought. Of the 75 activists I interviewed 14 considered themselves to be interested bystanders. They would occasionally attend the general assemblies of Occupy and were sympathetic to its values but were not involved in the day-to-day organizing processes of the movement.

Most of the interviews were conducted face-to-face, while 7 took place through other media, mainly telephone or Skype video calling. The interviews were unstructured and in-depth and most of them lasted between one and two hours. Questions focused on the interviewees' activist history and experience with politics, their involvement in the Occupy movement, as well as their use of and attitudes towards digital media. The interviews were transcribed and the main themes were identified through textual analysis. The interviewees were not anonymized but for issues of privacy I refer to them only with their first names.

The interviews were supplemented with the analysis of documents and social media material produced by the movement, such as the minutes of the general assemblies, press releases, statements, tweets and Facebook posts. To negotiate the wealth of online material produced by Occupy, I opted to focus on online content that was mentioned in examples and stories discussed in my interviews. I also collected material from the websites of Occupy London and Occupy Wall Street, concentrating on the statements and minutes produced by the assemblies. Some of the main Facebook pages created by the movement, such as Occupy the London Stock Exchange (henceforth OccupyLSX) and Occupy Wall St., were also scanned for the selection of topical examples to illustrate or provide accompanying evidence to the points made by activists in the interviews. The tweets and Facebook comments by individual users were anonymized in order to protect their privacy.

The combination of interviews with the textual analysis of online material allowed this study to provide insights into the attitudes, cultures and practices of Occupy activists and the ways these were expressed in the production of online content. While the focus of this paper lies on the role of 
social media, these are studied as part of the broader communication ecology of the movement (Treré, 2013) since the process of building a collective identity can traverse different platforms and physical spaces. The following sections report on the results of this study and outline three aspects of the process of 'identization': the drawing of boundaries between the inside and outside of the movement, the creation of foundational texts and codes, as well as the shaping of the movement's collective voice. While the occupations differed in their scope, intensity, composition and duration, in this paper I highlight some of the common themes instead of taking a comparative approach.

\section{Drawing the boundaries of the collective}

This section discusses how the communication spaces created or claimed by the movement help to define the boundaries of the collective in a flexible and fluid manner. Unlike other actors who have formal processes of recruitment and membership and well-defined roles, social movements tend to have more porous boundaries (Gerlach \& Hine, 1970). The processes through which one can become a member are not clear and they often simply involve the registration to an email list or the clicking of the 'like' button on Facebook. Thus, at any point in time, it is the people who have access to the different communication spaces of the movement who make up, informally, its membership. Some of these sites, such as email lists or social media pages serve as unofficial membership databases since they record personal information about the movement's supporters. The conversation sites of the movement are however characterized by different degrees of accessibility and visibility, as well as different capacities for communication. This affects the process through which the movement distinguishes between inside and outside and defines its boundaries.

In the case of Occupy, social media pages could be 'liked' and followed by anyone: interested members of the public, trolls, journalists and the police. They thus comprised both outsiders and people who considered themselves as part of the movement. This is reflected in the comments posted on the Occupy Wall St. (OWS) Facebook page where some users addressed the movement as 'you', speaking as sympathetic or critical outsiders: 
"I just want to say thanks to all of you standing up for us. We apprieciate [sic] you and are watching with baited breath. Stay strong!" (14 October 2011, Published on Occupy Wall St. Facebook page, https://www.facebook.com/OccupyWallSt)

"I don't want to be part of your 99\% lazy, welfare "I want your money without earning it" movement!!!!" (14 October 2011, Published on Occupy Wall St. Facebook page, https://www.facebook.com/OccupyWallSt)

Others employed the pronoun ' we', placing themselves inside the community created by Occupy:

"the system isn't working for any of us in the $99 \%$ and the dividing lines of political party, race, gender, religion have all been used to keep us from focusing on the real problem - corporate capitalism" (14 October 2011, Published on Occupy Wall St. Facebook page, https://www.facebook.com/OccupyWallSt)

Therefore, social media helped in diffusing the clear distinction between the inside and the outside of the movement. This blurring of the boundaries suited the movement's values of inclusiveness and direct participation, as well as its claims that it spoke for the $99 \%$ which made it difficult to, at least explicitly, exclude people from the movement. As one of my interviewees put it, 'part of what people wanted from the Occupy experience was to actually shatter that binary [between inside and outside]' (Leah, personal interview, January 27, 2014). The activists in charge of the social media pages were also at pains to stress the inclusive character of the movement as this status update from the Occupy Wall St. Facebook page demonstrates:

We just want to remind everyone that Occupy Wall St. is for the $99 \%$ ! Each and every one of you is included! Many people are concerned that this is becoming a strictly left-wing movement. That just is not true. Remember, this is not about pushing a specific political standpoint, it is about discussion between all of us. This is not an "us" vs. "them," this is everyone working together to make life better. (Occupy Wall St., 14 October 2011)

This reluctance to distinguish between insiders and outsiders also informed the practices of the activists responsible for the movement's social media pages. Thus, the unofficial guidelines for the OccupyLSX Facebook page, one of the main Facebook sites for the London occupation, advised editors to "[c]onsider followers as occupiers so avoid using too much "we" and "you". Occupy is open and we need to make followers feel like they're part of it.' (OLSX Facebook Guidelines for 


\section{Discussion).}

The accessibility and visibility of the different communication spaces of the movement also affected its internal stratification as social media followers formed an outer ring while the inner ring included activists who were participating regularly in the physical occupations. When asked about their involvement in Occupy, many of my interviewees talked first about the frequency with which they were visiting the camp or about whether they camped or not. In the mind of most activists, it was regular involvement face-to-face that actually rendered someone an 'Occupier'. Justin, an activist who was part of the media team of Occupy Wall Street (among other working groups) and one of the main people involved in tweeting for OWS, noted in this regard: 'we had the people in the park, that was one community. And there was this broader community of people who were watching over us.' (personal interview, January 22, 2014).

The inner ring also tended to include people who were subscribed to the email lists of the movement. The email lists were not broadly advertised on the website or the social media pages of the movement and thus operated predominantly as internal communication tools. When asked about the Occupy London listserv, Vica, who was active in the media team of Occupy St Paul's, noted: 'anyone can be added to it. The only thing is they're not sort of advertised anywhere. So like I can be telling you, "Look, there's this list and this is where you can get on them."' (personal interview, September 23 and 30, 2013). There is a marked difference here with movements of the pre-social media era, like the Global Justice Movement, where email lists served as the main online interactive spaces of the movement and were publicised widely on the movement's websites (Author, 2009b).

As the following section shows, this internal stratification of the movement, as well as the blurred membership status of social media followers also affected the process through which the movement's foundational codes and texts were created. 


\section{Creating common texts and codes}

The process of 'identization' involves the development of common practices, codes of conduct, demands and statements and their codification in 'texts'. Following Melucci, we can consider these codes both as artefacts and documents that encapsulate the movement's identity, and as practices or common ways of doing things. This was very much the case for Occupy, whose mode of decisionmaking operated as a foundational code that became part of the movement's identity (Gerbaudo, 2012; Graeber, 2012; Juris, 2012). Decision-making was based on open assemblies where participants agreed on common statements by consensus. The interaction was regulated by facilitators and had specific rules around turn-taking to ensure equal participation. These rules were developed early on (Graeber, 2012) and were codified in a various guides that were also uploaded online.ii

The general assembly was also crucial for the creation of the movement's foundational texts. For instance, the 'Principles of Solidarity of OWS', the main document outlining the values and demands of OWS, was produced in a series of discussions held at the assemblies (see NYCGA Minutes 9/23/11). All of the foundational texts are characterized as 'live documents', meaning that they could be changed at any time. This reluctance to fix the identity of the movement in official documents was facilitated by the use of digital media which allow for changes to be made to uploaded texts easily and quickly. In turn, the foundational texts and the minutes of the General Assemblies served as guidelines for the activists responsible for the social media pages of the movement and for those interfacing with the press and journalists. In my interviews with members of the press and media teams, activists stressed that these documents helped to orient the creation of content online as they gave them a sense of the movement's collective will.

The online spaces of the movement were used to broadcast and support the decision-making process taking place face-to-face. For instance, in OWS, the minutes of the meetings were uploaded on the www.nycga.net website. Activists also introduced a 24-hour rule, allowing people to submit proposals to be considered by the assembly up to 24 hours before the meeting (Marisa, personal 
interview, January 29, 2014). The general assembly was also live-tweeted and live-streamed and this material was uploaded online as a record of the movement.

However, this relegated the people participating online to spectators of the processes unfolding face-to-face. As Nafeesa, one of the prime livestreamers of Occupy London, noted, the people watching the general assemblies on livestream were at times given the opportunity to participate remotely by asking questions or making comments (personal interview, June 10, 2013). Yet, the principle of inclusiveness, the number and heterogeneity of people present, as well as the inexperience of some participants with politics meant that deliberation in the general assemblies was very time-consuming. Allowing people to participate remotely would have made this process even more unmanageable. Other research on Occupy, such as Mattoni's (2012) study of Occupy Pittsburgh, has noted similar concerns. Spyros, who was one of the main administrators of the Occupy LSX Facebook page, thought that the movement could have tried to involve people with different levels of engagement, instead of having 'one level, which was hardcore level of engagement' (Personal Interview, 9 June 2013). Tools that could have been employed to allow those on social media to have a say, such as petitions or e-voting, were not really used. As Spyros put it: 'at the end of the day what is democratic about like five people deciding the future of a movement that supposedly represents like thousands?' (ibid)

It is thus characteristic that one of the main purposes of social media pages was to mobilize followers to participate face-to-face as this status update from the Occupy Wall St. Facebook page clearly shows:

"Attend your local occupation. Be bold, Be Creative. This is not a protest movement. This is a movement of Liberation, Occupation, and resistance." (7 October 2011, Occupy Wall St., emphasis added)

This also became evident in the interviews. In this respect, Justin noted that 'to me the promise of tools like that, at their best, is that they bring people into physical engagement.' (personal interview, January 22, 2014) This is because participating face-to-face is thought to foster more long-lasting relationships. As Justin put it, 'even if they went out to their local Occupy, brought them a casserole or something, that's miles beyond clicking like on a Facebook page. That's about 
relationship building. And that lasts.' (ibid)

Still, for the activists on the ground, online spectators and their messages of solidarity were important for sustaining their commitment to the movement and for helping them to weather the difficult conditions of the physical occupation. This tweet from @OccupyWallStNYC attests to this point by comparing the 'internet' with a massive tarp that covers and supports the physical occupation:

"There is a massive tarp over \#LibertyPlaza tonight. It is YOU, Internet. \& no 1 can take this tarp down. \#sep17 \#takewallstreet" (20 September 2011, 11:49 pm)

The people participating on social media also played a crucial role in diffusing information about the movement and in providing feedback which in turn aided the movement's process of selfreflection. The 'likes' and comments served as useful metrics for the activists running the social media accounts of the movement, allowing them to evaluate the movement's resonance and success. In this regard, Spyros noted how following the metrics on the Facebook page helped him to draft guidelines for other content creators to ensure that the information they posted was engaging (personal interview, June 9, 2013). However, Mark, an activist for Occupy London who was involved in creating content for some of the social media pages, was more sceptical about the value of metrics, suggesting that they affect the activists' perception of success in a way that suits Facebook's corporate interests: 'And so, success is purely based on how many 'Likes' [...] To me, if you're getting ten thousand 'Likes' a week on Facebook, it means that whatever it is you're doing is translating to success in Facebook language. And Facebook language is "Free labour for Facebook".' (personal interview, September 27, 2013)

Therefore, the process of creating the common texts and codes of the collective was mainly undertaken face-to-face while social media played a supportive role as they were spaces for broadcasting the activities taking place in the physical space, through livestreaming and livetweeting. Online spectators were given few opportunities to intervene in the decision-making process of the general assembly. However, their participation was crucial for diffusing information 
about the movement, providing messages of support and solidarity to core activists, and for serving as metrics of engagement and success. As such, their role was instrumental for the sustenance and resonance of the movement.

\section{Bringing to life the collective voice}

The process through which the voice of the collective is brought to life is an important aspect of collective identity formation. Citing Tilly, Mattoni and Treré (2014) note that 'social movements are said to "take place as conversations" in which activists interact with "multiple audiences"' (p. 253). These conversations help the collective to reflect on and revise its identity and self-understanding. They also allow it to decide what its voice sounds like, who should voice it and based on what which processes and grounds of legitimacy.

Cooren's (2012) notion of ventriloquism can be useful in conceptualizing the process through which activists animate the collective voice and are in turn animated by it. He describes ventriloquism as '[t]he activity that consists of making someone or something say or do something' (p. 5) like a ventriloquist makes his dummy speak. However, the individual activists bringing to life the collective voice take both the role of ventriloquist and that of the dummy. This is because claiming to speak on behalf of a group signals that we are attached to it and we are thus equally animated, i.e. brought to life as spokespeople, in ways that are shaped by our association with the group and our position within it (ibid).

Like other movements before it, such as the Global Justice, Occupy's aversion to hierarchy and central leadership was accompanied by a rejection of the role of the spokesperson and the authority attached to it. In my interviews with members of the press and media teams, interviewees asserted that when they talked to journalists, they tended to conceal their real or full names. They also avoided taking on the role of the official spokesperson, identifying themselves as 'an activist from the Occupy movement'. In other words, they were presenting themselves as 'someone-as-anyone', a specific activist within Occupy that could be any other activist. This 
indicated that while every participant could talk to the media, no one was clearly authorized to speak as Occupy.

By contrast, social media platforms are designed in such a way that once a page or an account is set up under the Occupy name, the activists administering the account have to speak in the collective voice. For a movement that does not believe in spokespeople and who is unwilling to even fix its identity in formal documents, this was a source of unease. As this Occupy Wall St. status update shows, activists often stressed that despite appearances the Occupy social media pages did not represent the movement:

"[...] You should know that this or any other page does not speak for the movement. Attend your local GA or occupation and let your actions speak for yourself and stay united." (Occupy Wall St., 9 October 2011)

Therefore, the 'someone-as-anyone' strategy of erasing the special status of the spokesperson could not be undertaken on social media platforms. This was not for lack of trying. For instance, in Occupy Seattle the activists managing the Facebook page had a policy of adding their initials when they were publishing status updates as 'Occupy Seattle': "Finally someone is calling it what it is. kc" (Occupy Seattle Facebook page, 21 November 2011). This was an attempt to subvert the rules of the platform in a way that respected the belief of the movement in direct participation and the rejection of central leadership.

Regardless of these efforts, the design of social media platforms meant that the administrators of social media accounts had a significant role in shaping the collective voice. Thus, some occupations developed specific guidelines and management systems for the social media accounts of the movement. This was the case for one of the main Twitter accounts of Occupy Wall Street, @OccupyWallStNYC. The team administering the account was called 'Tweetboat', later renamed to 'Tweetship'. Requests to join the team had to be discussed by Tweetboat members and agreed by consensus. New members were added on Tweetboat with a 'Limited' permission and with one of the administrators acting as a mentor who was responsible for training the new member and approving her/his tweets before they were published (Tweeting for @OccupyWallStNYC). 
Tweetboat activists also had guidelines about the tone of the collective voice: 'Organizational twitter handle is for organization (movement). Not personal causes/shout-outs. Keep it relevant to our tweebs (followers). Avoid "I" statements (**except** when being arrested, when you can tweet in 1st person all you want!)' (Tweeting for @OccupyWallStNYC). The unofficial guidelines for the OccupyLSX Facebook page, quoted in the previous section, reveal similar concerns. Therefore, social media editors attempted to speak in a collective voice that was informal but inclusive, avoiding personal statements that, in Cooren's terms, would reveal the that the 'dummy' did not have its own voice but was instead animated by a ventriloquist.

Of course, this did not prevent some cases where the collective voice seemed to be at war with itself. For example, the @OccupyLSX Twitter account became divided in August 2012 over the movement's coverage of the Julian Assange case. On the 20th of August 2012, the following tweet appeared: 'Some of us think \#Assange is probably a rapist \#FreeBradleyManning". This attracted criticism from some followers, one of them asking activists to avoid using the movement handle to tweet their personal opinions. To that @OccupyLSX replied: 'We start our messages with "some of us", we never purport to speak on behalf of Occupy London.', thus challenging the notion that the organizational account was representing the movement as a whole.

There were also conflicts over the number of people creating content for specific accounts, as well as the processes of managing them. This was the case in London, when activists who were disgruntled with the management of the official Facebook page, Occupy LSX, created a different page, Occupy London, which was administered with a more horizontal structure (Nafeesa, personal interview, June 10, 2013). Struggles over passwords and administration rights were also very frequent. There were calls for such rights to be distributed more equally, as well as instances when one administrator barred the others in an effort to gain control of the account. For instance, in the first month of the London occupation, someone deleted all of the other administrators of the OccupyLSX Facebook page but eventually the issue was settled (Spyros, personal interview, June 9, 2013). Such incidents occurred in other occupations as well, like the one in Boston (Robin, personal interview, April 10, 2014). In New York, one of the main Occupy Wall Street accounts was hacked by 
Justine, one of the activists who had set it up, in order to tell her own story to the followers. Using the @OccupyWallSt handle, she tweeted on the $6^{\text {th }}$ of February 2014: 'This Twitter handle is now back under the management of its founder: @JustineTunney. Let's start a revolution.' Justine was severely criticised for breaching the rules and for using the organizational account on a personal capacity. She was also mocked for suggesting that she founded Occupy Wall Street. The Twitter hashtag \#IfoundedOccupyWallSt included thousands of sarcastic tweets and a community page was set up on Facebook - 'I founded Occupy Wall Street' - of which Justine is currently also member.

Thus shaping the collective voice of a movement based on inclusiveness and direct participation is a difficult process, but an unavoidable one on social media where activists have to speak as @Occupy. This process involves many negotiations and conflicts around who has access to the social media accounts and what this collective voice should sound like. The privilege of speaking as Occupy on social media was reserved to a few, an understandable choice but still one that challenged some of the movement's core values.

\section{Conclusion}

Social media are thought to facilitate looser and more personalized forms of collective action. They can operate as 'organizing agents' in the place of formal organizations, allowing quick coordination among diverse individuals (Bennett \& Segerberg, 2012). This has placed into question our conventional understandings of social movements and the value of traditional concepts, like collective identity, for explaining current patterns of collective action.

Yet, even if we accept that recent movements are more loosely structured than those of the past, these movements still need to develop their self-understanding as distinct collectives with their own agency. While much of the literature on 'organizing without organizations' focuses on decentralization, personalized communication and 'flash mobilizations', this paper investigates the more conventional processes of collective identity formation and the role of social media in creating the collective. Alongside other authors in this field, I attempt to develop a communication 
approach to collective action by combing insights from social movement theory and from organizational communication.

Melucci's (1996) theory is most useful in this regard as it conceptualizes collective identity as an open-ended, multi-layered and dynamic process through which a group negotiates internally the means and ends of its action and draws the boundaries with its environment. Yet in order to investigate the role of social media in this process, Melucci's conceptualization needs to be combined with theories from the field of communication to better explain the communicative aspects of the process of identization. Drawing from CCO, this paper views collective action as emerging in interconnected and overlapping texts and conversations that unfold in conversation sites with varying spatialities and temporalities. It thus investigates the communication processes that shape the collective identity of the movement and pays attention to how these are codified in 'texts'. At the same time, it explores how this process occurs on a variety of platforms and physical places, focusing specifically on the role of social media within this communicative ecology.

Based on interviews with Occupy activists from New York, London, Seattle and Sacramento, as well as the analysis of documents and online material, this paper shows that social media help to blur the boundaries between the inside and the outside of the movement in a manner that fits its inclusive character and its claims that it speaks for the $99 \%$. The activists' reluctance to openly exclude people from the movement meant that the process of boundary-making was indirectly shaped by the accessibility and visibility of the different conversation sites of the movement. These also played a role in the internal differentiation of the movement and in the demarcation between core Occupiers and more peripheral participants.

The general assemblies emerged as one of the key rituals of the movement, its physical embodiment and centre of legitimacy. It was the space where foundational texts of the movement were discussed and ratified or, in other words, where the identity of the movement was fixed, at least temporarily, in writing. Social media were used to broadcast and amplify the process of 'identization' taking place face-to-face. 'Likes' and comments were also useful metrics of the 
movement's resonance, allowing core activists to reflect on the movement's identity and increase its appeal to the public. Furthermore, social media users were important for supporting emotionally the core activists participating face-to-face, both through messages of solidarity and through more concrete activities, such as providing material support to the occupation. However, social media users were not provided with many opportunities to contribute to these internal processes of 'identization'. This was an issue of time and resources as many activists questioned the feasibility of a process where thousands could participate remotely. But it may also be due to the unacknowledged boundaries of the movement as, although not explicitly stated, the legitimacy to take decisions was accorded to the few who could attend the physical meetings.

The reluctance to acknowledge the boundaries of the movement also influenced the shaping of its collective voice. The movement's rejection of spokespeople and leaders meant that individual activists shied away from speaking as representatives of Occupy. The movement's collective voice emerged instead on social media where it engaged in conversation with a variety of actors. This is a result of the design rules of social media platforms which forced administrators and editors to speak as @Occupy. In this respect, the conflicts and guidelines over who can speak in the collective voice and what this voice should sound like are instructive. Despite all of the efforts to organize administration rights in a way that respected the values of inclusiveness and direct participation characterizing the movement, access to the collective voice was given to only a few activists. The guidelines urged activists to avoid 'l' statements or making distinctions between social media followers and core Occupiers. However, conflicts over administration rights were frequent, constituting evidence of the arduous negotiations that are necessary for a movement to find its voice.

The picture that emerges is complex. It demonstrates that proprietary platforms like Facebook and Twitter are designed in ways that may clash with the intentions of the activists using them. Yet, this analysis also shows that despite the emphasis on the role of social media in loosening and individualizing collective action, such platforms are important in the process of creating the collective. Viewing the movement as a phenomenon emerging in communication allows us an 
insight into the activists' efforts to create a collective that was both inclusive of the $99 \%$ and a distinctive actor with its own voice.

\section{References}

Author (2009a)

Author (2009b)

Author (2011, August)

Author (2013)

Author (2014, April)

Author (2014)

Barassi, V. and E. Treré (2012) ‘Does Web 3.0 Come After Web 2.0? Deconstructing Theoretical Assumptions Through Practice'. New Media \& Society, 14(8), 1269-1285.

Bennett, W. L., \& Segerberg, A. (2012). The Logic of Connective Action. Information, Communication \& Society, 15(5), 739-768. doi:10.1080/1369118X.2012.670661

Bennett, W.L., \& Segerberg, A. (2013). The Logic of Connective action: Digital media and the Personalization of Contentious Politics. Cambridge: Cambridge University Press

Bennett, W. L., Segerberg, A., \& Walker, S. (2014). Organization in the crowd: peer production in large-scale networked protests. Information, Communication \& Society, 17(2), 232-260. doi:10.1080/1369118X.2013.870379

Bimber, B., Flanagin, A., \& Stohl, C. (2012). Collective Action in Organizations Interaction and Engagement in an Era of Technological Change. Cambridge: Cambridge University Press.

Castells, M. (2012). Networks of Outrage and Hope: Social Movements in the Internet Age. Cambridge and Malden, MA: Polity.

Chadwick, A. (2013). The Hybrid Media System: Politics and Power. Oxford and New York: Oxford University Press.

Cooren, F. (2012). Communication Theory at the Center: Ventriloquism and the Communicative Constitution of Reality. Journal of Communication, 62, 1-20. doi: 10.1111/j.14602466.2011.01622.x

Cooren, F., \& Fairhurst, G. T. (2009). 'Dislocation and Stabilization: How to Scale Up from 
Interactions to Organization'. In L. L. Putnam \& A. Maydan Nicotera (Eds), Building Theories of Organization: The Constitutive Role of Communication (pp. 117-152). New York and London: Routledge.

Costanza-Chock, S. (2012). Mic Check! Media Cultures and the Occupy Movement. Social Movement Studies, 11(3-4), 375-385. doi:10.1080/14742837.2012.710746

Costanza-Chock, S. (2014). Out of the Shadows, Into the Streets! Transmedia Organizing and the Immigrant Rights Movement. Cambridge, MA and London: The MIT Press.

Dean, J. (2012). The Communist Horizon. London and New York: Verso.

della Porta, D., \& Mosca, L. (2005)/ Global-net for Global Movements? A Network of Networks for a Movement of Movements. Journal of Public Policy, 25(1), 165-190.

Fenton, N., \& Barassi, V. (2011). Alternative Media and Social Networking Sites: The Politics of Individuation and Political Participation. The Communication Review, 14(3), 179-196.

Flanagin, A. J., Stohl, C., \& Bimber, B. (2006). Modeling the Structure of Collective Action. Communication Monographs, 73(1), 29-54.

Flesher Fominaya, C. (2010). Collective Identity in Social Movements: Central Concepts and Debates. Sociology Compass, 4(6), 393-404. doi:10.1111/j.1751-9020.2010.00287.x

Fuchs, C. (2014). Social Media: A Critical Introduction. London: Sage.

Gaby, S., \& Caren, N. (2012). Occupy Online: How Cute Old Mena and Malcom X Recruited 400,000 US Users to OWS on Facebook. Social Movement Studies.

Gamson, W. A., \& Sifry, M. L. (2013). THE \# OCCUPY MOVEMENT : An Introduction. The Sociological Quarterly, 54(1), 159-163.

Gerbaudo, P. (2012). Tweets and the Streets: Social Media and Contemporary Activism. London: Pluto Press.

Gerlach, L. P. \& Hine, V. P. (1970). People, Power, Change: Movements of Social Transformation. Indianapolis: Bobbs-Merrill.

Gladwell, M. (2010). Small Change: Why the revolution will not be tweeted'. New Yorker, October 4 2010. Consulted on: July 7, 2011, from:

http://www.newyorker.com/reporting/2010/10/04/101004fa_fact_gladwell?currentPage=all.

Graeber, D. (2013). The Democracy Project: A History, A Crisis, A Movement. London: Random House. 
Johnston, H., Larana, E. \& Gusfield, J. R. (1994). 'Identities, grievances, and new social movements'. In H. Johnston, E. Larana \& J. R. Gusfield (Eds), New Social Movements: From Ideology to Identity, (pp. 3-35). Philadelphia, PA: Temple University Press.

Juris, J. S. (2012). Reflections on \#Occupy Everywhere: Social media, public space, and emerging logics of aggregation. American Ethnologist 39(2), 259-279. doi: 10.1111/j.15481425.2012.01362.x

Karpf, D. (2014). Comment on “Organization in the Crowd : peer production in large-scale networked protests ." Information, Communication \& Society, 17(2), 261-263. doi:10.1080/1369118X.2013.868020

Langlois, G., Elmer, G., Mckelvey, F., \& Devereaux, Z. (2009). Networked Publics : The Double Articulation of Code and Politics on Facebook. Canadian Journal of Communication, 34(3), 415434.

Lessig, L. (1999). Code: and Other Laws of Cyberspace. New York: Basic Books.

Mattoni, A. (2012, June). I Post, You Tweet, She Chats... And We All Occupy. Spaces of Participation and Communication in Occupy Pittsburgh. Paper Presented at the conference of the International Communication Association, London.

Mattoni, A., \& Treré, E. (2014). Media Practices, Mediation Processes, and Mediatization in the Study of Social Movements. Communication Theory, 24(3), 252-271. doi:10.1111/comt.12038

Melucci, A. (1996). Challenging Codes: Collective action in the information age. Cambridge and New York: Cambridge University Press.

NYCGA Minutes 9/23/11 (2011, September 23). Retrieved from http://www.nycga.net/2011/09/general-assembly-minutes-7pm-92311/

Occupy Wall Street Facebook Page. Retrieved from https://www.facebook.com/OccupyWallSt OLSX Facebook Guidelines for Discussion. Internal document shared privately with author.

Putnam, L. L., Maydan Nicotera, A. \& McPhee, R. D. (2009). 'Introduction' in L. L. Putnam \& A. Maydan Nicotera (Eds), Building Theories of Organization: The Constitutive Role of Communication (pp. 1-20). New York and London: Routledge.

Taylor, J. R. \& van Every, E. J. (2000). The Emergent Organization: Communication as Its Site and Surface. Mahwah, NJ and London: Lawrence Erlbaum Associates. 
Treré, E. (2012). Social Movements as Information Ecologies : Exploring the Coevolution of Multiple Internet Technologies for Activism. International Journal of Communication, 6, 2359-2377. Tweeting for @OccupyWallStNYC.Retrieved from bit.ly/TweetBoatRules

Van Dijck, J. (2013). The Culture of Connectivity: A Critical History of Social Media. Oxford and New York: Oxford University Press.

\footnotetext{
' It is worth noting that both Bennett and Segerberg (2013) and Gerbaudo (2012) cite some work from this approach. For an analysis of how CCO can be applied to social movement research see Author (2011, August) and Author (2014, April).

${ }^{\text {ii }}$ For instance, general assembly guidelines are available on the nycga.net website at http://www.nycga.net/resources/generalassembly-guide/
} 